Relations industrielles

Industrial Relations

\title{
Cobble, Dorothy Sue, ed. Women and Unions : Forging a Partnership
}

\section{Isik Urla Zeytinoglu}

Volume 48, numéro 4, 1993

URI : https://id.erudit.org/iderudit/050901ar

DOI : https://doi.org/10.7202/050901ar

Aller au sommaire du numéro

Éditeur(s)

Département des relations industrielles de l'Université Laval

ISSN

0034-379X (imprimé)

1703-8138 (numérique)

Découvrir la revue

Citer ce compte rendu

Zeytinoglu, I. U. (1993). Compte rendu de [Cobble, Dorothy Sue, ed. Women and Unions : Forging a Partnership]. Relations industrielles / Industrial Relations, 48(4), 778-778. https://doi.org/10.7202/050901ar

Tous droits réservés @ C Département des relations industrielles de l'Université Laval, 1993
Ce document est protégé par la loi sur le droit d'auteur. L'utilisation des services d'Érudit (y compris la reproduction) est assujettie à sa politique d'utilisation que vous pouvez consulter en ligne.

https://apropos.erudit.org/fr/usagers/politique-dutilisation/ 


\section{RECENSIONS BOOK REVIEWS}

Women and Unions: Forging A Partnership, edited by Dorothy Sue CoBbLe, Ithaca, N.Y., ILR Press, 1993, 452 p., ISBN 0-87546-301-0

This is one of the few books that focuses specifically on issues of interest to women and unions. All the important themes for the contemporary work world of women in the U.S. are covered in this book. It is clearly written with the U.S. audience in mind. Although it gives a few references from Western Europe and Canada, these are rare examples. Canadian readers will find that some of the accomplishments of Canadian unions, such as relatively higher unionization rate of part-time workers is not mentioned; similarly, the increasing visibility of women in leadership positions in Canadian unions is given a brief acknowledgement.

The book is written by more than forty authors under the editorship of Dorothy Sue Cobble. The contributing authors are coming from a wide range of backgrounds and includes academics, union organizers and staff, and government and independent policy makers. The book is written to stimulate an informed policy and practice approach for unions giving them some guidance on representing and working for the "new majority" - female workers. There are six sections in this book; each covering a specific theme. In each theme there are two to three articles written mostly by academics followed by comments from the practitioners. The first two themes are the ones that have been on the forefront of the feminist agenda since early 1970s: the differences in earnings and career opportunities for women and men, and meeting family needs. The book then follows with recent issues related to female workers: temporary and part-time work and the emergence of homework. Last two themes focus on organizing and representing female workers and the role of women in union leadership.

The book is structured as a series of conversations, which makes it easy to read while providing a gamut of information. The conversational style - used by some feminist researchers - encourages reader participation and thinking. Commentators raise issues not mentioned in the articles or give contrary views on issues discussed in articles, making the reader more attentive to controversies on an issue and forcing one to re-think the conventionally held views and opinions.

This book encourages the reader to think and to take an action. It is not written for those interested in getting definitive answers to questions or concerns. The book will be of interest to those concerned with the future of the U.S. labour movement. I would strongly recommend it to academics and practitioners, both men and women, from the industrial and labour relations field as well as to those from a variety of other fields including women's studies, sociology, labour history and social geography.

Isik Urla ZeYTINOGLU 